\title{
EFFEGTIVE TAX RATES: FACT OR FANCY?
}

\author{
Boris I. BITTKER †
}

\section{INTRODUCTION}

For at least twenty-five years, tax commentators have pointed out that the Internal Revenue Code's rate schedules, which now start with a rate of 14 percent and rise to a top rate of 70 percent, are misleading. One source of confusion is the difference between the marginal rate applicable to a taxpayer's final dollar of taxable income and the average rate applicable to his taxable income as a whole. ${ }^{1}$ A married couple with $\$ 20,000$ of taxable income, for example, is subject to a rate of 14 percent on their first $\$ 1,000$ and to gradually increasing rates on additional increments to their income, until a rate of 28 percent is reached on their last $\$ 4,000$ of taxable income. But their actual tax liability is $\$ 4,380$, or about 22 percent of their taxable income of $\$ 20,000$.

This difference between marginal and average rates is not the only source of confusion. Taxable income is the statutory tax base to which the statutory rates are applied, but it is not the only measure of the taxpayer's economic well-being. The couple just

† Sterling Professor of Law, Yale University. B.A. 1938, Cornell University; LL.B. 1941, Yale University.

Copyright (C) by Boris I. Bittker.

This Article is an expanded and revised version of part of the third of three lectures, given by the author in the Thomas M. Cooley Lecture Series, University of Michigan Law School, on April 4, 5, and 6, 1973. The first lecture and part of the second were published as Bittker, Income Tax "Loopholes" and Political Rhetoric, 71 Mich. L. REv. 1099 (1973), and Bittker, Income Tax Deductions, Credits and Subsidies for Personal Expenditures, 16 J. LAW \& Econ. 193 (1973).

I am much indebted to my colleague Marvin Chirelstein for his comments on a draft of this Article.

'See, e.g., R. Paul, Taxation for Prosperity 269-70 (1947):

In bemoaning high taxes, taxpayers commonly talk in terms of marginal rates, or the upper end of the rate schedule to which they are subject. Except in the very high brackéts [however] actual average rates, or effective rates, are much lower than marginal rates because of graduation and personal exemptions. ... Under 1945 law people who are subject to withholding think of their tax rate as 19 percent and people fortunate enough to be in the top bracket think of their tax as 86.45 percent. They would be happier and more accurate if they learned to think in terms of effective rates.

As will be seen, this early acknowledgment that the income tax's bark is worse than its bite melds together two different points: (1) the taxpayer's average rate, no matter what income base it is computed on, is lower than his top marginal rate on that base; and (2) the average rate is higher when computed on the statutory base ("taxable income") than when computed on a more comprehensive base. 
described, for example, may have received $\$ 25,000$ of gross income from wages and investments, from which $\$ 5,000$ was deducted to reflect their personal and dependency exemptions and optional standard deduction, leaving taxable income of $\$ 20,000$. Expressed as a fraction of gross, rather than taxable, income, their average rate of tax is only about 19 percent $(\$ 4,380 / \$ 25,000)$. A further inquiry into their financial affairs might disclose some economic benefits that were exempt from tax and hence omitted from their tax return, such as tax-exempt interest, ${ }^{2}$ a bequest, ${ }^{3}$ or the rental value of occupying their personal residence. ${ }^{4}$ If these exempt items were worth $\$ 10,000$, the couple could be described as enjoying $\$ 35,000$ of economic income. When their actual tax liability of $\$ 4,380$ is computed in relation to this amount, the average rate drops to about 12.5 percent $(\$ 4,380 / \$ 35,000)$.

Another calculation that is sometimes of interest is the tax that would be payable if the statutory rates were applied to either the couple's gross income of $\$ 25,000$ or their economic income of $\$ 35,000$, rather than to the taxable income base $(\$ 20,000)$ that is actually specified by the Internal Revenue Code. This hypothetical liability is $\$ 6,020$ if the statutory rates are applied to the alternative tax base of $\$ 25,000$ and $\$ 9,920$ if the alternative base is $\$ 35,000$, resulting in hypothetical average rates of about 24 and 28 percent of these alternative bases. Finally, the same couple's aggregate federal, state and local tax burden may be estimated and expressed as a fraction of their taxable income, gross income, or economic income, resulting in an average rate of total taxes for each of these bases.

When the taxpayer's actual income tax liability is expressed as a fraction of a base other than taxable income, the resulting percentage is usually described as the "effective rate." This label can be applied, for example, to both the 19 percent and the 12.5 percent rates in the illustration above. In computing effective tax rates, the tax theorist's objective may be merely to describe the economic impact of the tax, but often such a computation is the predicate for a criticism of existing law and a proposal for change. In polemical literature, for example, the difference between an effective rate of 19 or 12.5 percent on the couple described above and the 28 percent rate that would result if the statutory rate schedule were applied to their economic income of

2 INT. Rev. CODE OF 1954, § 103.

${ }^{3}$ Id. $\S 102$.

Thelvering v. Independent Life Ins. Co., 292 U.S. 371, 378-79 (1934). 
$\$ 35,000$ may be assailed as a "gap," reminiscent of the missile and credibility gaps of recent political life, that ought to be closed.

There are, however, many different ways to compute effective tax rates, generating-despite occasional references to the "true" or "actual" rate-as many computations as there are commentators. The resulting confusion can be illustrated by reference to the leading college text on economics, ${ }^{5}$ which contains a table to show "just how progressive the personal income tax really is," with average rates running up to 69.7 percent. A few paragraphs later, however, the reader is informed that these rates exist only "on paper," and that before the Tax Reform Act of $1969, "$ the effective rate on taxpayers with incomes over $\$ 1,000,000$ was not the amount set out in the table, but only 48.2 percent. This rate, in turn, is then described as "an overstatement if one takes account of many true income items that could be treated as low-taxed capital gains." 7 The rates vary in this exposition because the author uses the same dollar amount of tax liability but three different tax bases in making his calculations. A similar shift from one tax base to another explains why the effective rates in a table entitled "Individual Income Tax Liability and Effective Rates, for Selected Income Groups" in Historical Statistics of the L'nited States differ from those in an identically titled table in Statistical Abstract of the United States, published by the same government agency. ${ }^{8}$

These divergent calculations, which are only a small sample drawn from a large literature, share a common premise, viz., that the concept of "effective tax rates" is a useful tool of analysis. The purpose of this essay is to examine the validity of this basic assumption.

\section{The Measureient of Effective Tax Rates}

\section{A. The Effect of Progression}

Throughout this discussion, we will be concerned only with average tax rates, not with marginal rates. The distinction can be

\footnotetext{
$\therefore$ P. SAMLElson, Economics (9th ed. 1973).

'Act of Dec. 30, 1969, Pub. L. No. 91-172, 83 Stat. 487 (codified in scattered sections of INT. REv. CODE' of 1954).

7 P. Samlei.son, Economics 169-71 (9th ed. 1973). See also J. Due \& A. FriedlaenDer, Government Finance: Economics of the Public Sector 292 (table 11-2) (5th ed. 1973) (comparing the average marginal rates under 1966 law with effective rates based on taxable income, adjusted gross income, amended taxable income, and amended adjusted gross income).

${ }^{8}$ Compare Bl'real of the Census, U.S. Dep't of Commerce, Historical Statistics OF 'The UNited States, Colonial Times to 1957 at 702, 716-17 (table Y 319-32) (1960) with Bureat of The Censt's, U.S. Dep'r of Commerce, Statistical Abstract of the UNited STates, 1972 at 392 (table 622) (1972).
} 
illustrated with the aid of this extract from the schedule prescribed for married persons by $\$ 1(a)$ of the Internal Revenue Code:

If the taxable income is:

Not over $\$ 1,000 \ldots \ldots \ldots \ldots$

Over $\$ 1,000$ but not over $\$ 2,000 \ldots \ldots \ldots \ldots \ldots \ldots$.

Over $\$ 2,000$ but not over $\$ 3,000 \ldots \ldots \ldots \ldots \ldots \ldots$

Over $\$ 200,000$
The tax is:

$14 \%$ of the taxable income

$\$ 140$, plus $15 \%$ of excess over $\$ 1,000$

$\$ 290$, plus $16 \%$ of excess over $\$ 2,000$

$\$ 110,980$, plus $70 \%$ of excess over $\$ 200,000$

If a married couple has more than $\$ 1,000$ of taxable income, their average rate will always be lower than the marginal rate on the last dollar of their taxable income. Although Zeno's tortoise eventually got to the wall toward which he was crawling, the average rate on taxable income never quite reaches the top marginal rate of 70 percent. This is because the rate of tax on the first $\$ 200,000$ of taxable income of even the richest couple is less than 70 percent. $^{9}$

This progression-induced gap between marginal and average rates is important, because journalists often confuse marginal and average rates, nourishing the illusion that a taxpayer whose last dollar is taxed at the rate of 50 percent incurs an overall tax liability of 50 percent of his entire taxable income.

${ }^{9}$ A $70 \%$ average rate could be imposed on taxpayers with more than $\$ 200,000$ of income, but it would create a so-called "notch" anomaly by taking more than $100 \%$ of the last dollar of their income, thus leaving them less after-tax income than an otherwise comparable couple with somewhat less pre-tax income. To illustrate, under current law, a married couple with $\$ 200,000$ of taxable income pays a tax of about $\$ 111,000$ (average rate, 55.5\%), while a couple with $\$ 220,000$ of taxable income is taxed at the marginal rate of $70 \%$ on the last $\$ 20,000$ of income, producing an aggregate liability of about $\$ 125,000$ (average rate, $62.5 \%$ ). If the latter couple's average rate were boosted to $70 \%$, their after-tax income would be $\$ 66,000(\$ 220,000$ less tax liability of $\$ 154,000)$-much less than the after-tax income $(\$ 89,000)$ of the couple with only $\$ 200,000$ of taxable income, as the following table indicates:

Taxable income (before tax)

Less: $\operatorname{tax}$

After-tax income

\begin{tabular}{cc} 
Couple A & Couple B \\
$\$ 200,000$ & $\$ 220,000$ \\
111,000 & 154,000 \\
\hline$\$ 89,000$ & $\$ 66,000$
\end{tabular}

Thus, to bring the average rate on Couple B to $70 \%$, a tax of $\$ 43,000$ would have to be imposed on the last $\$ 20,000$ of their income. The last $\$ 20,000$ of Couple B's income was taxed, in effect, at the rate of $215 \%(\$ 43,000 / \$ 20,000)$.

To avoid this "notch" paradox, under which a taxpayer can worsen his after-tax status by improving his pre-tax status, the progressive rate schedules have consistently permitted the taxpayer's average rate to lag behind his marginal rate. 
But the contrast between marginal and average rates, though central to the very concept of progression, is not the source of the "gap" with which tax theorists are concerned. Indeed, the rate schedules of current law, which use marginal rates, could be converted by simple arithmetic into tables of average rates. Average-rate schedules would be inordinately long, because a different rate would have to be written into law for every level of taxable income, but they could impose the same total tax liability at each income level as the rate schedules of current law. Thus, the tax liability of married couples with taxable income from $\$ 1,000$ to $\$ 2,000$ (described in a single line of the schedule above) could be set forth in a rate schedule of this type:

Taxable income

$\$ 1,000$
$\$ 1,010$
$\ldots \ldots$
$\$ 1,990$
$\$ 2,000$

Rate (percent)

14.0000

14.0099

$\cdots \cdots$

14.4975

14.5000
Liability

$\$ 140.00$

$\$ 141.50$

$\$ 288.50$

$\$ 290.00$

As this alternative presentation demonstrates, ${ }^{10}$ the marginal rates prescribed by current law are merely an abbreviated way to impose the desired average rates.

For this reason, the fact that progression causes the taxpayer's average rate to lag behind his marginal rate plays no role in the phenomenon under investigation. We will be concerned exclusively with the fact that taxable income-the base used in the discussion above-is only one of numerous bases that can be plausibly used in computing the average rate of tax on a given taxpayer's income.

\section{B. Nomenclature}

Turning now to the competing ways of computing average tax rates, the best starting point is a formula for deriving the type of average rate just described:

Formula A

$$
\text { Rate }=\frac{\text { actual tax liability }}{\text { statutory tax base (taxable income) }}
$$

${ }^{10}$ The table would be even more extended if $\$ 1$ intervals were used, rather than the $\$ 10$ intervals in the text. Moreover, separate tables would be required for the four taxpaying units recognized by the Code, unmarried individuals, married couples, heads of household, and married persons filing separately. Additional complexities would be added by the capital gains provisions and certain other special rules of current law. 
When applied to the married couple descrribed at the beginning of this article, who incurred a tax liability of $\$ 4,380$ on taxable income of $\$ 20,000$, Formula A yields an average rate of about 22 percent:

$$
\frac{\$ 4,380 \text { (actual tax liability) }}{\$ 20,000 \text { (taxable income) }}=22 \%
$$

As we saw, however, some economic benefits received by this couple were excluded from their taxable income. If the average rate is to reflect these items, a different formula must be used:

$$
\begin{gathered}
\text { Formula B } \\
\text { Rate }=\frac{\text { actual tax liability }}{\text { alternative base }}
\end{gathered}
$$

Depending on whether the alternative base used in applying Formula B to the couple is their gross income $(\$ 25,000)$ or their "economic income" $(\$ 35,000)$, the rate is 19 percent $(\$ 4,380 / \$ 25,000)$ or 12.5 percent $(\$ 4,380 / \$ 35,000)$. These two rates, however, do not exhaust the possibilities under Formula B. The composition of the alternative base used in Formula B depends on the preferences and judgments of the commentator, and every change in the way the base is defined will cause a change in the rate yielded by the formula. The alternative bases that have been used in computations of this type include "adjusted gross income," "amended adjusted gross income," "expanded adjusted gross income," "adjusted family income," "total income," "amended taxable income," and "amended gross income." 11 Despite this smorgasbord of possibilities, it is common

${ }^{11}$ For computations of effective rates of individual income taxes using such bases, see J. DUE \& A. FriedlaEnder, supra note 7, at 292 (table 11-2) (adjusted gross income, amended taxable income, amended adjusted gross income); R. GOODE, THE INDIviduAL INCome Tax 326 (table A-10) (1964) (total income); House Comm. on Ways \& MEANS \& Senate Comm. on Finance, 91 st Conc., 1st Sess., Tax Reform Studies and Proposals, U.S. Treasurr: DeP'T, pt. 1, at 81 \& table 5 (Joint Comm. Print 1969) (amended taxable income, amended adjusted gross income); H. TARAsov, Who PaYs THE TAXES? (TNEC Monograph No. 3, 1941) (consumer income); TAX Foundation, TAX Burdens and Benefits of Government EXPenditures by InCOME Class, 1961 and 1965, at 20 (table 7) (1967) (total income); Gillespie, Effect of Public Expenditures on the Distribution of Income, in Essays in Fiscal Federalism 122, 125-28, 135-36 (tables 3 \& 4) (R. Musgrave ed. 1965) ("broad" income concept, "adjusted broad" income concept); Hearings on H.R. 8363 Before the Senate Comm. on Finance, 88th Cong., 1st Sess., pt. 1, at 279 (1963) (amended gross income); Herriot \& Miller, The Taxes We Pay, 8 Conference Board Record, May 1971 , at 31, 40 (table 7) (total income) (hereinafter cited as Taxes); Herriot \& Miller, Changes in the Distribution of Taxes among Income Groups: 1962 to 1968, in 1971 Proceedings of the Business and Economics Statistics Section, American Statistical AssN. 106, 108 (adjusted total income) (hereinafter cited as Changes); Pechman, Distribution of Federal and State Income Taxes by Income Classes, 27 J. Fin. 179, 182-83 (1972) (adjusted family income); Pechman \& Okner, Individual Income Tax Erosion 
practice for each commentator to describe the rate resulting from applying Formula $B$ to his preferred alternative base as "the" effective or actual rate. Of course, the more a commentator's alternative base differs from the Internal Revenue Code's definition of taxable income, the greater the disparity between the Formula $A$ rate, which might be called the apparent rate, and the effective rate derived from Formula $B$.

Once a theorist has fixed on an alternative tax base for use in Formula $B$, he may wish to go on to compute the tax that -would be payable if the statutory rate schedule were applied to the alternative base, and then to convert this hypothetical liability into an average rate on the alternative base. This entails the use of a third formula:

$$
\begin{gathered}
\text { Formula } C \\
\text { Rate }=\frac{\begin{array}{c}
\text { hypothetical tax liability } \\
\text { alternative base }
\end{array}}{}
\end{gathered}
$$

For the couple in our example, the tax liability would be $\$ 6,020$ if their gross income of $\$ 25,000$ were subjected to the statutory rate schedule, resulting under Formula $\mathrm{C}$ in an average rate of about 24 percent $(\$ 6,020 / \$ 25,000)$, while the hypothetical liability on their economic income of $\$ 35,000$ would be $\$ 9,920$, or an average rate under Formula $\mathrm{C}$ of about 28 percent. Rates computed under Formula $\mathrm{C}$ are often described as nominal rates. ${ }^{12}$

All three of these formulas generate average rates. Although the statutory rate schedule, with its graduated marginal rates, is used to calculate the numerator of all three fractions (the actual tax liability in Formulas A and B and the hypothetical tax liability in Formula $\mathrm{C}$ ), marginal rates play no further role in the computation. The result in each case, therefore, is an average rate.

Moreover, all three of these average rates could be described as effective rates, since each depicts the portion of the base on which it is computed that is consumed by taxes. An effective rate, in other words, is simply a percentage of a particular base; the

by Income Classes, in Joint Economic Committee, 92D Cong., 2D Sess., The Economics of Federal Subsidy Programs, pt. 1, at 13 (Joint Comm. Print 1972) (reprinted in Brookings Institution Reprint No. 230, 1972) (expanded adjusted gross income).

For computations of the effective rate of corporate income taxes, see 119 CoNs. REc. H7165 (daily ed., Aug. 1, 1973) (study by Congressman Vanik); House Comm. ON Ways \& Means \& Senate Comm. on Finance, 91 st Cong., Ist Sess., Tax Reform Studies and Proposals, U.S. Treasury Dep't., pt. 3, at 458-61 (Joint Comm. Print 1969) (economic income of financial institutions).

${ }^{12}$ Formula $\mathrm{C}$ rates are also occasionally referred to as statutory rates, although the only statutory feature of such a rate is the use of statutory marginal rates to compute a hypothetical tax liability on a hypothetical tax base. This Article will use throughout the term "nominal rate." 
term is meaningless unless the base is specified. This means that even marginal rates are effective rates when measured by their own bases. The top marginal rate of 70 percent, for example, represents an effective rate of 70 percent on all taxable income. above $\$ 200,000$. But it is customary in tax analysis to reserve the term "effective rate" for the percentages derived from Formula $B$, and to use the term "nominal rate" for Formula C. Formula A lacks a generally accepted tradename, but perhaps the label "apparent average rate" serves to convey its meaning.

\section{Adjusted Gross Income}

Although almost every commentator employs a different alternative base in computing effective rates, the usual starting point is adjusted gross income (AGI), ${ }^{13}$ an amount that the theorist then expands or contracts in accordance with judgments that will be discussed shortly. Since AGI can thus be regarded as common ground, and moreover is sometimes used without change in the computation of effective tax rates, ${ }^{14}$ it deserves to be examined first. Disregarding refinements, AGI consists of all receipts that are subject to tax, such as salary, dividends and interest, and business profits, less business expenses, but undiminished by personal exemptions or such personal deductions as medical expenses, alimony, interest on home mortgages, and charitable contributions.

Since the taxpayer's AGI is always greater than his taxable income, the effective rate of tax is lower if computed as a percentage of AGI than if based on taxable income. The items deducted from AGI, such as the taxpayer's personal exemptions, are in effect taxed at a zero rate. Thus, according to the Treasury Department, the tax paid by the average taxpayer with $\$ 1,000$ to $\$ 2,000$ of adjusted gross income amounted to 14.5 percent of his taxable income but only 1.2 percent of his adjusted gross income, while the average taxpayer with $\$ 1,000,000$ of adjusted gross income or more paid a tax of 67.5 percent of taxable income but only 49 percent of adjusted gross income. ${ }^{15}$

${ }^{13}$ INT. Rev. Conf of $1954, \S 62$. A less common starting point for the computation of an alternative tax base is an overall indicator such as net national product, from which a concept of individual income is derived. See, e.g., TAx FolNdation, Tax Burdens and Benefits of Government Expendrtures by Income Class, 1961 and 1965 at 1-2 (1967); Herriot \& Miller, Taxes, supra note 11, at 31; Herriot \& Miller, Changes, supra note 11, at 106, 110; Pechman, supra note 11, at 182.

14 See Paul, Erosion of the Tax Base and Rate Structure, in Subcoms. on Tax Pol.Ic: of the Joint Comm. on the Economic Report, 84th Cox(.., 1st Sess., Federal. Tax Policy for Economic Growth and Stability 297, 299-300 (Comm. Print 1955).

15 Internal Revence Service, U.S. Dep't of The Treasury, Statistics of Income-1971, Individual. Income Tax Returns (Prel.iminary) 6 (table 1) (1973). 
Because a taxpayer's AGI is ordinarily the amount available to him for personal expenditures, it is usually regarded as a better base for effective tax rate computations than taxable income. For a taxpayer at the bottom of the income ladder, however, a computation based on taxable income-the balance after personal exemptions and the low income allowance have been deducted-may be more illuminating. Consider an urban family of four with AGI of $\$ 5,000$, whose 1972 tax liability is $\$ 100$. Expressed as a fraction of AGI, this liability is only 2 percent, but it is 14 percent of the family's taxable income of $\$ 700$. Since the family's income is only about $\$ 800$ above the urban poverty line, and a sizeable part of this margin must be paid to the Treasury, the statement that their effective tax rate is 14 percent ( $\$ 100$ tax on $\$ 700$ of taxable income) may convey a more accurate picture of their financial sacrifice than the statement that they are taxed at only 2 percent $(\$ 100$ tax on $\$ 5,000$ of AGI). The expert can readily place either rate in proper context; but if a journalist or political orator describes one as "the" effective rate, he will imply that the tax either imposes a hardship on the family (" 14 percent of income") or is trivial ("2 percent of income"), depending on which of the two arithmetically correct rates he chooses.

For another example, consider a couple with $\$ 50,000$ of adjusted gross income, but only $\$ 10,000$ of taxable income because of deductible casualty losses and medical expenses caused by a fire that destroyed their home and injured their children. Assuming a tax liability of $\$ 2,000$, they can be described as paying 4 percent of their AGI $(\$ 50,000)$ or 20 percent of taxable income $(\$ 10,000)$. Either way, the arithmetic is impeccable. In choosing between these rates, the analyst implicitly expresses an opinion on the propriety of allowing taxpayers to deduct medical expenses and casualty losses. If the commentator disapproves of or barely tolerates these deductions, he is likely to assert that the "true" effective rate is only 4 percent. ${ }^{16}$

These percentages are averages for each income class; the effective rate on any individual taxpayer may be higher or lower than the average. The dispersion is especially pronounced for effective rates based on AGI, since each AGI class embraces taxpayers with a wide range of taxable incomes.

16 I have argued elsewhere, however, that these deductions are, in general, consistent with the Haig-Simons definition of income. Bittker, Income Tax Deductions, Credits and Subsidies for Personal Expenditures, $16 \mathrm{~J}$. Law \& Econ. 193 (1973). If accepted, this line of argument suggests that effective tax rates are more illuminating if computed on a base that takes these deductions into account, and that in the example just described, the couple's burden is better described as $20 \%$, rather than $4 \%$, of their available income. See also Andrews, Personal Deductions in an Ideal Income Tax, 86 HARv. L. REv. 309, 331-43 (1972). 
The choice between taxable income and AGI as a measure of the taxpayer's effective rate is further complicated by several technical aspects of AGI, which account for some of the striking examples recently offered of millionaires who pay no tax. Although AGI ordinarily reflects the taxpayer's disposable income after allowing for his business expenses and losses, it does not always do so. One of the much-publicized 106 taxpayers with AGI of $\$ 200,000$ or more who paid no taxes in 1970 , for example, reported $\$ 400,000$ of gambling winnings and an offsetting loss of $\$ 400,000$ from the same activity, with the result that his federal income tax liability was zero. ${ }^{17}$ Because the $\$ 400,000$ of profit was included in his AGI while the loss was deducted "below the line" (i.e., deducted from AGI in computing taxable income), he appeared as a taxpayer with $\$ 400,000$ of AGI and no tax liability. He attained this distinction, however, only because he was unusually scrupulous in complying with the Internal Revenue Code's technical definition of AGI. ${ }^{18}$ Many taxpayers in similar circumstances would simply have offset the loss against the income and reported that their AGI was zero.

This statutory separation of income from its offsetting deductions is not unique to gambling, but extends to a number of other activities and transactions as well. According to the Treasury, 75 of the 106 nontaxable returns with AGI over $\$ 200,000$ claimed very large deductions for interest and other investment expenses incurred in profit-oriented transactions. These were deducted "below the line," while the gross income derived from the same transactions entered into the taxpayer's AGI. ${ }^{19}$ When large amounts are involved, the unexplained use of AGI as a base in computing effective tax rates is misleading. To invoke a private law analogy, if a businessman with AGI of $\$ 1,000,000$ and investment expenses of $\$ 900,000$ reported to his creditors that his income was $\$ 1,000,000$ rather than $\$ 100,000$, they would no doubt charge him with fraud. This may be too severe a label for the statistical arguments of politicians, but the audience to which an AGI analysis is addressed should at least be put on notice that a taxpayer's AGI may greatly exceed the amount available to defray his personal expenditures.

Adjusted gross income, then, sometimes overstates the taxpayer's gain by failing to take account of expenses incurred in

${ }^{17}$ Hearings on Tax Subsidies and Tax Reform Before the Joint Economic Comm., 92d Cong., 2d Sess. 158 (1972) (remarks by Under Secretary of the Treasury E.S. Cohen).

${ }^{18}$ INT. REv. CODE OF 1954, \& 62.

${ }^{19}$ Hearings on Tax Subsidies and Tax Reform Before the Joint Economic Comm., 92d Cong., 2d Sess., at 157-58 (1972). 
earning income. But this is neither its only, nor ordinarily its most important, deficiency as a base for computing effective tax rates. It can err in the opposite direction, understating the taxpayer's gain by omitting items that improve his economic position. This is because AGI is a creature of the Internal Revenue Code, computed after the exclusion or deduction of such perennial candidates for tax reform as exempt interest on state and municipal bonds, ${ }^{20}$ the untaxed half of long-term capital gains, ${ }^{21}$ and percentage depletion, ${ }^{22}$ as well as numerous less controversial receipts, such as sick pay, ${ }^{23}$ employer contributions to qualified pension and profit-sharing plans, ${ }^{24}$ and meals and lodging furnished to the taxpayer for the convenience of his employer. ${ }^{25}$ To take items like these into account in computing effective tax rates, it is necessary to construct a new base, corresponding to the taxpayer's "economic" or "true" income.

\section{Economic Income}

For many years it was difficult for tax analysts to break loose from AGI as a base in computing effective tax rates, despite its deficiencies, because the Treasury Department's official statistical summary of individual income tax returns classifies taxpayers by AGI levels. The advent of the computer and the preparation of a master statistical tape with the details from a representative sample of 90,000 personal income tax returns ended this bondage to the Internal Revenue Code's definitions, by enabling tax statisticians to create an alternative hypothetical tax base, or a variety of such bases, broken down by income classes. ${ }^{26}$ As a result, tạx liabilities imposed by current law can be expressed, for each income class, as a percentage of whatever new base is selected for comparison and analysis. It is also feasible to apply the statutory rates to the new base, and thus derive the nominal rate described by Formula $C$ above. ${ }^{27}$

The new base may be created by taking the information now appearing on tax returns and putting it together in a different form, for example by adding the untaxed one-half of long-term

"2" INT. REv. CODE OF 1954, \$103.

21 Id. \$ 1202.

22 Id. $\$ 613$.

${ }^{23}$ Id. $\$ 104$.

${ }^{24}$ Id. $\$ 404$.

${ }^{25} I d$. $\$ 119$.

${ }^{26}$ See Okner, Constructing a New Data Base from Existing Microdata Sets: the 1966 Merge File, 1 Annals of Econ. \& Soc. Measurenent 325, 326 n.2 (1972), summarized in Pechman \& Okner, supra note 11, pi. 1, at 13-16. See also Comm'n to Revise the Tax Structure, Reforming the Federal Tax Structure 147-55 (App. A) (1973).

${ }^{27}$ See text accompanying note 12 supra. 
capital gains to adjusted gross income. To achieve a broader concept of "economic income," the analyst may revise the data on the returns by replacing statutory methods of computing income with methods that he deems more accurate, such as substituting straight-line depreciation for accelerated depreciation and cost for percentage depletion. He may go further afield, by imputing receipts that the return itself does not report or even hint at, like tax-exempt interest and unrealized appreciation, and by adjusting for assumed errors by the taxpayer, employing a combination of statistical extrapolation, educated inferences and guesswork.

In an imaginative and painstaking effort of this type, Pechman and Okner, of the Brookings Institution, converted AGI into a more comprehensive tax base, which, although influenced by the Haig-Simons definition of income, also embodied the authors' judgments on debatable issues of fairness, administrative practicality and political reality. ${ }^{28}$ When the tax liabilities imposed by existing law are expressed as percentages of this broad base, denominated "expanded adjusted gross income," the effective tax rates range from 0.5 percent on income under $\$ 3,000$, to 32.1 percent on income of one million dollars and above. ${ }^{29}$ The top rate of 32.1 percent on this base compares with a top effective rate of 49 or 67.5 percent when taxable income or AGI, respectively, is used as the base. ${ }^{30}$ When the statutory rates are applied to the Pechman-Okner tax base, using Formula $\mathbf{C}$ above, revenue rises from $\$ 103$ billion to $\$ 180$ billion-an increase of $\$ 77$ billion. ${ }^{31}$

The Pechman-Okner effective rates would be lower if their comprehensive tax base had included unrealized appreciation, gifts and bequests, employer contributions to private pension plans, and some other items that they regard as embraced by an economic concept of income but that they excluded from their comprehensive base for reasons of administrative convenience or historical precedent. On the other hand, the Pechman-Okner rates would have been higher if they had preserved some of the present law's other exclusions, such as public assistance, unemployment insurance, workmen's compensation, and social security; and the extra exemptions for aged and blind taxpayers. ${ }^{32}$

${ }^{28}$ Pechman \& Okner, supra note 11 , pt. 1, at 16-21.

${ }^{29}$ Id. 22 (table 2).

${ }^{30}$ Internal Revenue Service, U.S. Dep't of the Treasury, Statistics of INCOME-1971, Individual INCOME TAX RETURNS (PreliminaRy) (1973).

${ }^{31}$ Pechman \& Okner, supra note 11, pt. 1, at 22-23 (tables 2 \& 3).

${ }^{32}$ Id. 16-21. 
The leverage exerted by the assumptions that underlie the tax base that is used to compute effective tax rates can be illustrated by a later study from the Pechman-Okner computer, which uses "adjusted family income" as the base. ${ }^{33}$ Because this concept is substantially broader than the base used in the earlier Pechman-Okner study, since retained corporate profits are imputed to the taxpayer and all personal deductions and exemptions are denied, the effective rates computed on this base are substantially lower for all taxpayers above the $\$ 10,000$ income level. A third recent study, similar in methodology but contrasting in its assumptions, can be usefully compared with the two Pechman-Okner studies. ${ }^{34}$ Its tax base includes unrealized appreciation and depreciation, employee fringe benefits, corporate income (whether distributed or undistributed), scholarships and fellowships, mortality gains on life insurance, and some other currently untaxed items, generating a set of effective tax rates that differ markedly from both Pechman-Okner computations.

But these three studies by no means exhaust the possible variations on the effective tax rate theme. By taking into account the value of services performed in the home, allowing a deduction for net savings, adjusting for inflation, or adopting still other tax reform proposals, one can create a host of other tax bases, each of which would yield a different set of effective tax rates. Indeed, each can be made to yield several sets of effective rates, by varying the taxpaying unit-by aggregating the income of minor children and their parents, for example, or by dividing the joint income of married couples between husband and wife.

Thus, whenever an effective rate of tax is computed not as a mathematical curiosity, but as the foundation of a normative conclusion about the tax system, the base-whether it is taxable income, adjusted gross income, or some variety of "economic income"-embodies a myriad of value judgments. These threshold judgments, often implicit rather than explicit, amount in the aggregate to an assertion that the components included in the base are relevant to taxpaying capacity, and that those excluded are not. It follows that the process of defining the base used in computing effective tax rates is comparable to the process of criticizing the Internal Revenue Code, and that there are as many effective rates as there are "ideal" Internal Revenue Codes. At the core, these alternative measures of the taxpayer's

${ }^{33}$ Pechman, supra note 11 .

${ }^{34}$ Comm's to Revise the Tax Structure, Reforming the Federal Tax Structure (Fund for Public Policy Research) (Galvin, Willis, et al.) (1973). 
effective rate overlap, since all of them include such fundamental items as salaries and business profits while excluding such equally fundamental items as business expenses and the cost of goods sold. There are, however, enough differences in the treatment of many other items to provide a cornucopia of effective rates. With this array of computations to choose from, a journalist or political orator can safely describe the income tax structure as severely-or barely-progressive. He will rarely be called upon to explain, and will often not know, that the alternatives reflect divergent judgments about the items that should be taxed or taken into account in measuring taxpaying capacity.

\section{Are the Statutory Rates Sacrosanct?}

So far, we have been concerned primarily with comparisons between the effective rate on taxable income and the effective rate on the commentator's alternative nonstatutory base, in which both calculations employ the actual tax liability under existing law (Formulas $\mathrm{A}$ and $\mathrm{B}$ above). But recent discussions often entail a second comparison-between the effective rate of actual tax on the proposed alternative base (Formula B) and the rate of the hypothetical tax liability that would result from applying the statutory rate schedule to the alternative base (Formula $\mathrm{C}$ ). This comparison unveils a disparity between the "effective" and "nominal" rates whose width depends on how far the commentator travels from existing law; the greater his dissatisfaction with the Internal Revenue Code's concept of taxable income, the wider the gap.

After calling attention to the gap, critics of existing law sometimes assert, explicitly or implicitly, that the American public has been misinformed or even betrayed. In the words of one recent study of the tax system: "The only possible purpose of such a gap [between nominal and effective rates] is to trick the American public into thinking that its preferences for a progressive income tax are being implemented when they are not." ${ }^{35}$ At its most optimistic, the betrayal theory implies that the public's commitment to the progressive rate structure is so powerful that, once the obstacles to its achievement are exposed, they will be swept away. A similarly critical, but less heated, reaction to the "gap" is annoyance that society is unwilling to admit what it is doing. "Impose whatever rates you want," the observer seems to be saying, "but don't preach progression unless you are willing to

${ }^{35}$ L. Thurow, The Impact of Taxes on the American Economy 154 (1971). 
practice it." ${ }^{36}$ Sometimes the tone is less evangelical than bemused, as though a detached observer were calling attention to a pathetic social effort to worship both progression and financial success.

The betrayal theory has much in common with the notion that the Internal Revenue Code is a vast "welfare program for the rich," riddled with loopholes that are known to crafty lawyers and their clients but hidden from public view. ${ }^{37}$ Both views are equally out of touch with the facts of life. To begin with, there is no single rate schedule. The schedules for single persons, married couples and heads of households are all parts of a legislative whole, and so are the special rate applicable to long-term capital gains, the zero rate applicable to state and municipal bond interest, and the Code's numerous deductions and exclusions. All have been enacted by Congress, and if one part of this complex rate structure is better known and more widely endorsed by the public than another, it is by no means clear that it is the 14 to 70 percent marginal rate schedule.

To escape the inconvenient fact that the entire Code, not just a few sections, was enacted by Congress, it may be argued that the rate structure-the 14 to 70 percent ladder and the average rate resulting from these marginal rates-embodies the General Will, but that all provisions narrowing the tax base reflect craven surrenders to special privilege. But this is not a promising way to analyze as complex a product of the political process as the Internal Revenue Code, whose major departures from a comprehensive tax base ("preferences") are tenaciously defended by an extraordinarily wide spectrum-"coalition" would not be a misnomer-of taxpayers. Among other defects, this approach treats such major components of the tax structure as income-splitting, capital gains, personal deductions and exemptions, accelerated depreciation, and the realization concept as though they were protuberances stealthily grafted onto the Code in a legislative twilight.

There are, of course, innumerable statutory excrescences that confer benefits exclusively on special interests in the narrowest sense.$^{38}$ But these provisions, however objectionable, account for only a small part of the tax gap at issue. Its real causes

\footnotetext{
${ }^{36}$ See Musgrave, How Progressive is the Income Tax?, in 3 House Comm. on Ways \& Means, Tax Revision Compendium 2223, 2230 (1959).

${ }^{37}$ See Stern, Uncle Sam's Welfare Program-For the Rich, N.Y. Times, Apr. 16, 1972, $\S 6$ (Magazine), at 28 , col. 1 .

${ }^{38}$ See Cary, Pressure Groups and the Revenue Code: A Requiem in Honor of the Departing Uniformity of the Tax Law, 68 HaRv. L. Rev. 745 (1955).
} 
are provisions like those listed above, and they are as prominent and persistent a part of the tax system as the rate schedule itself. Indeed, during the two decades since enactment of the 1954 Code, these structural provisions have been repeatedly expanded by Congress while the rate differential has been explicitly narrowed, from a maximum average rate of 87 percent in 1954. to less than 70 percent today or, in the case of earned income, 50 percent. $^{39}$ Judged by history, if one can speak of a national commitment to a progressive rate schedule, there is an equally powerful commitment to a less-than-comprehensive tax base.

In thus rejecting the "betrayal" theory, I do not mean to imply that all tax provisions are equally worthy of preservation, or that more public exposure would not be salutary. My point, rather, is that the statutory rate schedule cannot be insulated against reexamination when other major aspects of the Code are being criticized. Since there are no objective standards for judging the fairness of the rate structure, the social scientist may wish to treat it as a revealed social preference, and then argue that provisions narrowing the tax base (e.g., personal deductions, percentage depletion, accelerated depreciation, and the capital gains deduction) undermine this sacrosanct social judgment. It is obviously tempting for the analyst to say: "I am announcing no personal preference, but am instead performing the neutral analytical function of demonstrating that Congress has failed to deliver what it promised." The trouble with this forensic posture, of course, is that the Internal Revenue Code's statutory rates and its less-than-comprehensive base are interrelated parts of a single whole. Thus, if one is a revealed social preference, so is the other. Both come from Capitol Hill, which, though less lofty than Mount Sinai, is the only nonsectarian source of revelation in our society. This does not mean that whatever is, is right, nor does it embody the error of thinking that "the political system works perfectly, and society never makes mistakes."40 It does mean that there is no neutral proof that the political system worked correctly in fixing tax rates but erred in defining the tax base. In short, the statutory rates cannot properly be "held constant" while the statutory base is simultaneously denounced as a betrayal of the public's wishes.

Indeed, it is wholly unlikely that proponents of the betrayal theory would want an across-the-board elimination of the gap

${ }^{39}$ Int. Rev. Code of 1954, § 1348; J. Pechman, Federal Tax Policy 225 (table A-1) (rev. ed. 1971).

${ }^{10} \mathrm{~L}$. ThuRow, supra note 35 , at 163 . 
between effective and nominal rates (i.e., between Formulas $\mathrm{B}$ and $\mathrm{C}$ ), despite their protestations. In 1969, for example, the effective tax rate for taxpayers with $\$ 1,500$ to $\$ 2,000$ of "total income" (as defined) was only about one fiftieth of the nominal rate, while it was about one-half of the nominal rate for taxpayers with income of $\$ 1$ million or more. ${ }^{41}$ To turn from averages to individuals, I call attention to the hypothetical family of four with AGI of $\$ 5,000$, described earlier, ${ }^{42}$ whose tax would rise from $\$ 100$ under existing law to $\$ 810$ if the statutory rate were applied to their "total income" by use of Formula C. Most critics of the "gap" would surely prefer the effective rates now applicable to such low income taxpayers over the nominal rates, despite their professed allegiance to the revealed social preferences embodied in the latter. ${ }^{43}$

A similarly ironic reversal of emphasis is illustrated by Senator McGovern's ill-fated original tax proposal of 1972, which coupled a flat nominal rate of 32.5 percent on a broad base with a tax credit ("demogrant") of $\$ 1,000$ per capita. The arithmetic of the proposal was a gross tentative tax of $\$ 340$ billion, reduced by the credits to a net yield of $\$ 126$ billion. $^{44}$ The resulting gap of $\$ 224$ billion between the nominal yield of the proposed tax and its effective yield was 3 times the $\$ 77$ billion gap under existing law. ${ }^{45}$ The Senator, therefore, quite rightly wished to persuade the public that the effective rates were what counted, and that the nominal rate was only a technical device. His opponents, understandably, repeatedly pointed to the nominal rates as proof of McGovern's true objective-his "revealed social preference," as it were.

A study mentioned earlier complains that "[i]nstead of making social value judgments clear and explicit [in the area of taxation], deliberate efforts are made to hide special privileges." ${ }^{46}$ But how, for example, can a political decision to tax capital gains at a lower rate than othèr income be made more "clear and explicit" than by a law taxing capital gains at a lower

$41 \mathrm{~J}$. Pechman, supra note 39, at 298-99 (table C-11).

42 See text following note 15 supra.

${ }^{43}$ In the case of low income taxpayers, the gap is largely attributable to the statutory personal exemptions, which are sometimes described as part of the rate schedule. See, e.g., Musgrave, supra note 36 . Though this theory implies pro tanto there is no gap to be closed, the numerous versions of "economic income," see sources cited note 11 supra, are almost always computed before exemptions, thus broadening the gap between nominal and effective rates to which Thurow and others object. See L. Thurow, supra note 35.

${ }^{44}$ See Bittker, Income Tax "Loopholes" and Political Rhetoric, 71 Mich. L.R. 1099, 1123-26 (1973); G. HART, Right FROM THE StaRT 190-94 (1973).

45 Pechman \& Okner, supra note 11.

${ }^{46} \mathrm{~L}$. Thurow, supra note 35 , at 154 . 
rate than other income? The commentator's own remedy is as follows: "To insure that the public knows what is occurring it is ... necessary to implement a requirement that tax laws be written in such a fashion that nominal and effective rates can not differ by other than trivial amounts." 47 The recommendation is appealing until one thinks about how it could be enforced. Unless Congress provides that criticism of the Internal Revenue Code is treason, anyone can advocate enactment of a tax base that differs substantially from the statutory base (e.g., including unrealized appreciation and imputed income in the base or, if they are included by law, excluding them), and that is all one needs to prove by using Formulas $B$ and $C$ that there is a more than "trivial" gap between the nominal and effective rates. Aside from forbidding advocacy of a change in law, the only way to insure that nominal and effective rates do not differ is to enact a tax base commanding such unanimous allegiance that another could not be envisioned. Faith in this alternative calls to mind the Duke of Wellington's response when a hapless governmental clerk accosted him with the greeting, "Mr. Jones, I believe?" The Duke's reply: "If you believe that, you'll believe anything."

\section{The Impact of Other Taxes}

So far, we have been concerned with effective income tax rates, which take account of the personal income tax and, less frequently, the corporate income tax to the extent that its burden falls on the corporation's individual shareholders. Because the effect of income taxes, whether progressive, proportional or regressive, can be reinforced or counterbalanced by state, local and other federal taxes, tax scholars have sought to measure the aggregate effective rate of all taxes, using the taxpayer's income as the base. ${ }^{48}$ Since the taxes that are to be brought into the consolidated formula are not based on the taxpayer's income but on a wide variety of other events and transactions, they must somehow be allocated among taxpayers by reference to income, rather than according to the taxpayer's participation in the

${ }^{47}$ Id. 155.

${ }^{48} \mathrm{~A}$ pioneering effort is $\mathrm{H}$. TaRasov, supra note 11 . Later studies include: Tax Foundation, Tax BuRdens and Benefits of Government Expenditures by Income Class, 1961 and 1965 (1967); Gillespie, Effect of Public Expenditures on the Distribution of Income, in EsSays In FISCAL Federalism 135-36 (tables 3 \& 4) (R. Musgrave ed. 1965); Herriot \& Miller, Changes, supra note 11; Herriot \& Miller, Taxes, supra note 11; $R$. Musgrave \& P. Musgrave, Public Finance in Theory and Practice 366-72 (1973).

For discussion of the interesting fact that these consolidated measures use income rather than some other economic characteristic as the computational base, see notes 55-58 infra \& accompanying text. 
activity generating the particular tax liability. Thus, the retail sales tax is paid by taxpayers when they purchase goods and services for consumption, with the result that the aggregate amount paid is proportional to each taxpayer's expenditures for taxable items. If this amount is to be consolidated with other taxes paid by a taxpayer to determine the percentage of his income that is absorbed by taxes, however, it must be expressed as a fraction of his income rather than as a fraction of his purchases. A similar conversion is required in order to bring real property taxes, gift and inheritance taxes, excise taxes and other levies into the consolidated formula.

The allocation to taxpayers at each income level of taxes that are deductible in computing federal taxable income can be based either on the deductions actually taken by them or, in the case of taxpayers who elect the standard deduction in lieu of itemizing their personal deductions, on inferences from the amounts deducted by itemizers. More debatable inferences are required to allocate by income classes such nondeductible taxes as federal excises and federal and state death taxes, and the process becomes even more attenuated if taxes are to be allocated to persons who do not pay the tax but who bear its economic burden. Corporate income taxes, for example, eventually fall on natural persons, but economists are not agreed on whether the burden is borne by the shareholders of the corporations paying the tax, or is shifted to consumers, employees and suppliers, or investors generally. The effective rate of federal and state corporation income taxes is very sensitive to the choice among these assumptions. According to one study, for example, the effective rate for taxpayers with adjusted family income of one million dollars and over is 40 percent if the tax is allocated to shareholders, but only 19 percent if it is allocated among all investors; and the rate would be still lower if the tax was treated as shifted to consumers. ${ }^{49}$

Although these computations of effective consolidated tax rates invariably assume that some taxes are passed on by the nominal taxpayers to purchasers of their goods and services and

${ }^{49}$ Pechman, supra note 11 , at 187 (table 4). See generally R. MusGrave \& P. Mus: GRAVE, supra note 48, at 354-72; Mieszkowski, On the Theory of Tax Incidence, $75 \mathrm{~J}$. Pol. ECON. 250 (1967); and my legal fantasy based on the shifting of taxes, Bittker, The Case of the Fictitious Taxpayer: The Federal Taxpayer's Suit Twenty Years After Flast v. Cohen, 36 U. CHI. L. Rev. 364 (1969).

For a powerful argument that "the very concept of the incidence of a corporation income tax or other broad-based tax as such is invalid" and that econometric studies attempting to measure the incidence of such taxes "necessarily reveal nothing about this nonexistent phenomenon," see C. Shoup, Public Finance 11-19 (1969); see also Prest, Statistical Calculations of Tax Burdens, 22 ECONOMICA 234 (1955). 
that the latter should be viewed as the real taxpayers, the contrary assumption-that the economic burden of the tax remains on the taxpayer who is required by law to pay it-is universally employed in determining who pays the personal income tax. This assumption is based on the theory that a taxpayer cannot charge more for his goods and services than those of his competitors who pay no income tax because they are operating at the break-even point, and who therefore fix their prices without regard to income taxes. ${ }^{50}$ The theory that income taxes are not business expenses that can, or must, be passed on to purchasers of the taxpayer's goods and services is buttressed by the theory that the prices that will maximize a taxpayer's profits before income tax will also maximize his post-tax profits. $^{51}$ Thus, the enactment of an income tax, or an increase in the rates of an existing tax, provides neither an incentive nor an opportunity to increase prices; if there had been any slack in the market, the taxpayer would have already increased his prices to absorb it.

This is not the place for a critical examination of the assumption, in discussions of vertical equity, that the income tax rests where it is imposed. But I wish to call attention to two puzzling aspects of the assumption, while leaving detailed examination of the issues to the economists. Some students of the corporate income tax assert, and a larger number accept the possibility, that the tax is shifted to some extent to the corporation's customers. ${ }^{52}$ But if the classical axiom that income taxes cannot be shifted is to give way in this instance, it is difficult to exclude the possibility that the personal income tax is shifted to the same extent by unincorporated enterprises, such as sole proprietorships and partnerships, that compete with corporate businesses. And if this possibility is entertained, is it not also possible that there is some shifting by persons who are in the business of providing personal services, such as self-employed professionals and even wage-earners and salaried employees?

The computation of effective tax rates is complicated still further by the fact that income taxes alter the relationship

${ }^{50}$ This theory, of course, assumes that a tax on income can be distinguished from other types of taxes, such as taxes on the privilege of conducting the business, on the use of property, on the payment of wages, etc. I know, however, of no effort to specify the characteristics of an income tax that are presupposed by the traditional no-shifting theory. Does it presuppose, for example, that net worth changes are taken into account currently, or that all taxpayers must use the same method of computing depreciation?

31 For a discussion of the arguments for and against this proposition see Pechman, supra note 39 , at $112-13$.

${ }^{52}$ See discussions and studies listed by authors cited notes 48-49 supra. 
between work and leisure for taxpayers engaged in the performance of services. The taxpayer derives a lower net yield from his work, while the pleasures of leisure are unchanged. By itself, this decrease in the relative value of work would impel him to substitute leisure for labor. This "substitution" or "price" effect of the tax, however, runs counter to its "income" effect, since to regain his preexisting level of disposable income, he will have to work harder. The income effect of the tax may be more powerful than its substitution effect for taxpayers at some income levels, and less powerful at others; and it would be astonishing if the point where they come into equilibrium was not affected by the taxpayer's age, sex, marital status, education, religion and philosophical outlook. If these variables are not distributed on a random basis among taxpayers, but are linked with occupational choices, the work-leisure impact of income taxation may alter the prices of goods and services offered on the market, and thus affect pre-tax incomes.

The fact that income and taxes are interdependent variables was once described in a discouragingly cosmic metaphor:

The stone thrown into the ocean makes ripples which, as they diminish in height with the widening of the circles, may extend-could we but measure their infinitesimal magnitude-to shores thousands of miles away. And the light rays which their movement deflects from the courses these rays would otherwise follow, may pursue their new way through the stellar universe far past the remotest stars of which the telescope informs us. Similarly, the effects, could we consider all of them in their (possibly) increasing variety though (probably) diminishing intensity, of any given tax, may extend through the future to and beyond the time when human beings shall have ceased to tenant the earth. ${ }^{53}$

This was written before the age of Sputnik, and it might be thought that the same computer which now plots interstellar travel could follow the ripples of an income tax to the farthest reaches of the universe. But technological advances in the processing of numbers have not been accompanied by comparably improved ways to measure human impulses. As a result, the calculations disgorged by the computer are no better than the imprecise guesses that it feeds on, though the precision of the output can easily blind the layman to the deficiencies of the input.

${ }^{53}$ H. Brown, The Economics of Taxation 12-13 (1924). 


\section{What are Effective Tax Rates Good For?}

What are calculations of effective tax rates good for? If the limitations just described are discounted as needlessly finicky, overcome by improved techniques, or simply disregarded, do the computations tell us anything useful about the world we live in? For example, if an astronaut with $\$ 25,000$ of economic income is subject to an effective consolidated tax rate of 20 percent, leaving him with $\$ 20,000$ of after-tax income, can we properly infer that a revision of the tax laws to exempt him from all taxes would increase his take-home pay from $\$ 20,000$ to $\$ 25,000$ ? The obvious answer is that this inference would be reasonable if the legislation is confined to John J. Arcturus, of 4201 Mars Blvd., Cape Canaveral, Florida.

But the assumption that his disposable income would increase by the amount of his former tax burden would be absurd if extended simultaneously to all taxpayers. Without taxes, there would be no government, or at least no government except by unanimous consent. To assume that today's pattern of pre-tax income would continue in this awesome state of affairs is as fatuous as telling someone who sleeps a third of every day that kicking the habit would give him eight extra hours a day for work.

Recognizing that without taxes, there would be no public expenditures, an occasional economist volunteers for the heroic task of describing the pattern of income that would prevail in "a world without taxes and [governmental] expenditures." In such a utopia, we are told by a recent study, adult men would work less while women and teenagers would work more, producing in the aggregate "a 2.5 percent increase in the average hours of leisure." 54 However comforting this conclusion may be to my generation of male parents, it is probably not the last word on the subject, and the methodology on which it rests is still in its infancy. But the author's premise of a complex interrelationship between taxes, governmental expenditures and income is irrefutable.

This critical interrelationship is easily misunderstood or overlooked by the layman when he is confronted by a table of pre-tax incomes, effective tax rates and post-tax incomes. It is all too easy to conclude from such a tabular presentation that taxes reduce everybody's income in the way they seem to reduce the reader's individual income. From this oversimplified conclusion, 
it is only a short step to still another: that changes in taxes affect only the taxpayer's post-tax income. In fact, however, pre-tax income is what it is partly because taxes are what they are. To illustrate the point with hypothetical round numbers, for all individual taxpayers as a class, $\$ 800$ billion of pre-tax personal income less $\$ 200$ billion of taxes equals $\$ 600$ billion of post-tax income, but it is equally true that $\$ 600$ billion of post-tax income plus $\$ 200$ billion of taxes equals $\$ 800$ billion of pre-tax income. Neither formulation tells us whether the chicken or the egg came first.

As a guide to political action, therefore, calculations of effective tax rates-even if they did not depend on so many debatable assumptions-must be used with caution. At the margin, they suggest that raising the rates here and lowering them there or repealing this tax and substituting that one would nudge us toward or away from equality, and they provide a clue to the size of this change in after-tax income. To predict the impact of more exhilarating changes, however, they are gravely deficient unless revised to reflect the consequential changes in the distribution of pre-tax income. When these changes have been absorbed, the after-tax distribution of income may be quite different from what was predicted, because the tax innovation may alter pre-tax income more than it alters after-tax income. The outcome, in short, may be closer to, or farther from, the status quo ante than was predicted or desired.

\section{VI. "Income" as the Base for a Consolidated TaX}

Earlier in this article, I described attempts to compute the consolidated burden or effective rate of all types of taxes by income classes. ${ }^{55}$ The fact that some species of income is used as the computational base in these projects is worthy of attention. Why is the consolidated burden portrayed as a percentage of the taxpayer's income, rather than calculated by reference to such other characteristics as the taxpayer's consumer expenditures, wealth, net worth change, occupation, age or real property? Why does the analyst allocate taxes on cigarettes by reference to the taxpayer's income, for example, but refrain from allocating income taxes by reference to the taxpayer's purchases of cigarettes?

Occasionally, to be sure, we encounter calculations that allocate the tax burden on a per capita basis, such as statements

${ }^{\text {ss }}$ See text accompanying notes $48-53$ supra. 
that "every man, woman, and child in the United States pays an average tax of $\$ 3$ per day" or that "the per capita tax burden in the United States is twice, or one-half, the per capita burden in Sweden or Paraguay." Similarly, we are sometimes told that taxes constitute X percent of every dollar paid for whiskey; and when a big truck passes me on an interstate highway, I sometimes discern through the haze of its exhaust an announcement that "This truck pays $\$ 17,456$ per year in taxes." But the purpose of calculations like these is rhetorical rather than normative: to shock the reader, not to assert that taxes should be levied on a per capita, per bottle or per truck basis.

When personal tax burdens are computed as a percentage of the taxpayer's income, however, the computation almost always embodies a normative assumption, viz., that the fairness of the aggregate tax burden depends on its relation to the taxpayer's income. This premise clearly underlies efforts to compute the effective rate of the income tax itself, leading to claims that the tax is too progressive or not progressive enough, or that it is more or less progressive than the layman is led to believe. More important, the same premise underlies calculations of the burden of taxes that are not explicitly related to the taxpayer's income. When we are told, for example, that a state retail sales tax imposes a heavier burden on low income than on high income taxpayers, the assertion is not intended as evidence that the poor buy more taxable goods than the rich. The point, rather, is that their sales tax burden, computed as a percentage of income, is greater than the sales tax burden on rich taxpayers. The assumption, of course, is that the fairness of the burden. should be judged by translating the absolute amount paid into a percentage of income; and the comparison implicitly rejects the idea that fairness is insured by the fact that the tax is a fixed percentage of each dollar spent for taxable goods, or by the fact that the average poor person buys fewer taxable goods than the average rich person.

Similarly, when local real property taxes are expressed as percentages of income, the implicit assumption is that the relationship is not a curious statistic, but the basis for a normative judgment. During the 1972 presidential campaign, for example, President Nixon favored federal aid to the states to finance a 50 percent reduction in local property taxes, asserting that the highest priority should be given to elderly retired persons with incomes of less than $\$ 2,000$ a year, "who on the average pay a 
property tax of $33 \frac{1}{1} 3$ percent of that income." The President went on to say: "Now that is fiscally wrong, morally wrong, and certainly tax wrong." 56 A similar assumption underlies Professor Heller's endorsement of the per capita credit (so-called "circuit breakers") granted by some state retail sales taxes: "These refinements are aimed at converting the sales tax into a progressive tax. Through this interlocking of sales and income taxes, we may yet make a silk purse out of a sow's ear." 57 A similar desire to "make a silk purse out of a sow's ear" can be discerned in suggestions that a federal value-added tax could be devised with exemptions for low income taxpayers so that its burden would not be regressive when measured by the taxpayer's income.

The use of income as a normative base, whatever the formal base may be for a particular tax, is not confined to theoreticians and political spokesmen, but has received formal congressional endorsement. The allocation of revenue-sharing grants under the State and Local Fiscal Assistance Act of 1972 depends in part on the state's "tax effort," measured by a formula that relates its aggregate tax collections to the aggregate personal income of its population. ${ }^{58}$ The formula springs from a legislative premise that a state's effort to help itself should be judged by reference to the personal income of its residents rather than by reference to such other characteristics as their expenditures, net worth, real property or current savings.

This pervasive acceptance of income as the normative base for taxation suggests that the logical next step would be to replace. all federal, state and local taxes by a single federal income tax, coupled with grants by the federal government to states and cities. If the fairness of each individual tax is to be judged by its relationship to the taxpayer's income and its capacity to make up for the deficiencies of those of its teammates falling short of the ideal, why not go for the real thing at the outset by enacting a Single Tax on Income to achieve directly. what individual taxes imposed on a variety of bases can only grope for?

There are, of course, constitutional provisions, political

${ }^{56}$ New York Times, Oct. 6, 1972, at 28, col. 3 .

57 W. Heller, New Dimensions of Political Economy 131-32 (1966). But see Hearings on S. 1255 Before the Subcomm. on Intergovernmental Relations of the Senate Comm. on Governmental Operations, 93d Cong., 1st Sess. 40-46 (1973) (Statement of H. Aaron).

5831 U.S.C. \& 1225 (1970). See S. REP. No. 1050, 92d Cong., 2d Sess. 12-13, 30-34 (1972). The House bill went further down this road by explicitly favoring states with an income tax, but this provision was dropped in conference. See S. REP. No. 1229, 92d Cong., 2d Sess. (1972); Calaba, The Analysis and Application of the State and Local Fiscal Assistance Act of 1972, 28 TAx L. REv. 377 (1973). 
forces, and institutional factors that preclude such a national Single Tax on Income as a viable legislative proposal. Even as an ideal, however, it has its limitations. Some tax provisions are not intended to distribute the burdens of government according to a social judgment on the taxpayer's ability to pay, but to discourage or encourage particular activities, such as the smoking of cigarettes, the emission of pollutants, the discovery of oil, or the construction of low-cost housing. The distributional effects of such a provision are important, and if found to be objectionable might in some circumstances lead to a revision or abandonment of the original objective. But if the provision's distributional impact is an acceptable price for the incentive or deterrent effect of the provision in question, its repeal and the substitution of a Single Tax on Income would sacrifice important social objectives. A computation of effective tax rates that is based solely on income encourages this sacrifice of values by narrowing the reader's angle of vision.

\section{Allocation of Governmental Expenditures}

The fairness of a tax system cannot be judged without taking account of the governmental benefits it makes possible. From an ethical perspective, a tax levied to finance welfare payments is not the same as an identical tax to build a municipal polo field. Thus, a computation of effective tax rates is ethically neutral, when viewed in isolation; what counts is fiscal, rather than tax, fairness. Recognizing this, economists and other social analysts have endeavored to allocate the benefits of public expenditures to the citizenry, classified by income class. The objective is a distribution of both benefits and burdens, permitting each income group's benefits to be compared with its taxes in a consolidated display of the global incidence of the nation's fiscal system..$^{59}$

But any such allocation of governmental benefits encounters a familiar problem in political economy-the absence of a free market to establish the citizen's own evaluation of benefits he derives from governmental expenditures. Without a toll gate to exclude free loaders from public education, highways, or other social goods and services, we do not know what any citizen or

59 Herriot \& Miller, Changes, supra note 11. For conceptual difficulties in such allocations, see Aaron \& McGuire, Public Goods and Income Distribution, 38 Econometrica, Nov. 1970, at 907; Weisbrod, Income Redistribution Effects and Benefit Cost Analysis, in Problems in Public Expenditure Analysis 177 (S. Chase ed. 1968); C. Galvin \& B. Bittker, The Income Tax: How Progressive Should It Be? $48-54$ (1969). 
group of citizens would have been willing to pay for these benefits, or how much they have consumed. If it were possible to deaden the free-loader instinct with a truth serum, we could ascertain what a particular public good is worth to each user. Pending this improvement in medical technology, analysts who allocate governmental expenditures by income class must choose from a range of plausible assumptions that is unfortunately even broader than the spectrum used to allocate the tax burden.

A recent allocation divided the $\$ 215$ billion of aggregate public expenditures for 1968 into two groups: those for which "a reasonable allocation series" was thought to exist, and those that could be allocated only by adopting one of several "arbitrary assumptions." 60 For the latter group, consisting of national defense and related expenditures amounting to $\$ 129$ billion or 60 percent of the total, the alternative assumptions were that the allocation should be per capita, proportional to income, or proportional to wealth. As might be expected, the assumption chosen exerts enormous leverage on the result. Allocating these expenditures by wealth assigns almost 27 percent to persons with $\$ 50,000$ of adjusted money income or more, while a per capita allocation credits them with only 0.6 percent. For taxpayers at the bottom of the income spectrum (under $\$ 2,000$ of adjusted money income), on the other hand, a per capita allocation credits them with almost 13 percent of these expenditures while an assignment by income gives them only 1 percent.

But there is a wide choice of alternatives not only in allocating the benefits of expenditures for national defense and the like, but also when expenditures for education, health and social welfare are involved. The study just described treated these items, which amounted to 40 percent of the total, as assignable to individuals on the basis of direct personal participation in the relevant programs. Thus, expenditures for education were assigned to families with children in public schools and colleges, federal aid to hospitals was allocated to persons using veterans' and other government hospitals, and welfare and social security payments were assigned to their recipients. But it would be entirely reasonable to assign these expenditures, at least in part, to persons other than those who participate directly in the programs in question, just as the cost of maintaining the Naval War College is not allocated to the officers who attend the courses. Some, indeed, may believe that expenditures for social

${ }^{60}$ Herriot \& Miller, Changes, supra note 11. 
welfare are merely premiums paid by those who are well-off for insurance against civil disorder and that what the poor receive is either an incidental externality or a "public bad" rather than a "public good" because it saps their enthusiasm for social change. Even if one rejects this view as too cynical or class-oriented, there is merit in the theory that the quality of everyone's life is enhanced by public education, and that the rich are benefited if the poor do not have to sleep in the streets. ${ }^{61}$ To divide these expenditures between direct participants in the programs and others who derive indirect benefits, one must adopt an arbitrary formula; but to disregard the indirect benefits is equally arbitrary.

By an irony of timing, the concept of a consolidated measure of fiscal fairness had barely become an accepted tool of analysis when a crucial assumption of such computations came under heavy fire. Disenchantment with GNP as a measure of economic welfare carries with it a refusal to regard aggregate governmental expenditures as synonymous with benefits. If some expenditures produce "bads" rather than "goods," should this not be recognized before passing judgment on the fiscal system's fairness? The pioneering Tobin-Nordhaus "Measure of Economic Welfare" excludes "regrettable expenses" such as the cost of national defense, adjusts for the "disamenities of urbanization," and makes other allowances for adverse and neutral economic costs in measuring economic well-being. ${ }^{62}$ Though acknowledged by its authors to be "primitive and experimental," this effort to come to grips with GNP's anti-growth critics carries an interesting implication for the measurement of fiscal fairness, viz., that similar adjustments should be made in computing the benefits of governmental expenditures before allocating them by income classes. Indeed, the concept of income itself could be profitably reexamined in the light of the Tobin-Nordhaus analysis of economic welfare.

Adjustments of this type, it hardly needs saying, entail a host of judgments before the computer can be programmed. Once again, we find that a balance sheet of government benefits and burdens consists of numbers whose precision belies the debatable social and political judgments on which the computation rests. Behind the computer, there is always a moral philosopher.

61 This fact underlies efforts to describe a "pareto-optimal" distribution of income. See Brennan \& Walsh, Pareto-Optimal Redistribution Reconsidered, 1 PuB. FIN. Q. \#147 (1973) \& articles cited.

${ }_{62}$ Nordhaus \& Tobin, Is Growth Obsolete?, in Economic GrowrH (Nat'l Bureau of Econ. Research, Colloquium III, VKOL. V, 1972). 


\section{CONCLUSION}

Judgments about equity in the tax system ultimately depend on deep-seated political and philosophical convictions, which in turn are linked in a complex fashion with economic interests. The most that can be expected of the tax analyst is a description of the way the tax burden is allocated among income or other relevant classes. The analyst's role begins with a recognition that the statutory rate schedule tells us little about the actual distribution of the tax burden. This insight is illustrated by the original McGovern tax credit plan, which taxed all income at the same nominal rate, but then reached a progressive result by allowing a per capita credit against this hypothetical tax liability. As we explored the techniques used by the analyst to compare the nominal and effective tax rates, however, it became painfully clear that no table or graph is better than its footnotes, and that the footnotes are almost always replete with debatable assumptions. As a result, the existence of a gap between the nominal and effective rates is a neutral bit of information, which should lead to a value judgment only if the hypothetical base used by the analyst in computing the effective rates is regarded by the informed citizen as preferable to the statutory tax base to which the nominal rates are applied. Even then, a gap that would be offensive if judged solely by the citizen's equity criterion may be salvaged if, in his view, it advances a social or economic objective that he prizes, such as low-cost housing, pollution control or economic growth.

A careful reading of the footnotes to a table of tax burdens will do more than expose its threshold assumptions. It will also disclose other reasons why the naked statistics may be a deficient foundation for policy recommendations. First, the statistics rarely if ever reflect the troublesome fact that pre-tax income is affected in real but obscure ways by the tax system. It is misleading, for example, to portray tax-exempt interest as subject to a zero effective rate if the yield on state and municipal bonds is lower than the yield on taxable securities of comparable quality. For policy purposes, it would often be more realistic to regard the investor as subject to an implicit tax; and the fact that it is difficult to estimate the appropriate amount does. not improve the quality of tax-burden computations that treat it as zero, but rather illustrates one of their deficiencies. Of more global significance, and even more difficult to assess, is the fact that the pre-tax income of all taxpayers is affected by the tax system, but 
that their ability to shift the burden may vary with their income level, occupation, age and other characteristics. Judgments about equity would be badly undermined if it turned out that the tax burden of substantial groups of taxpayers have been neutralized-or accentuated-by changes in their pre-tax income. This possibility may be minimized by neoclassical economic theory, but it cannot be excluded.

Moreover, when the tax analyst endeavors to provide a comprehensive portrait of the distribution of all taxes, rather than to analyze the income tax in isolation, the problem of shifting is even more acute. If the theorist adopts the reasonable tactic of providing alternative computations, each based on a different set of economic assumptions, the reader must make his own selection, a task for which his qualifications may be minimal.

Finally, an ethical judgment about the tax burden can hardly disregard governmental expenditures financed by the tax system in question. One wants to know who benefits before deciding who should pay. Here again, however, the analyst can supply a framework, but the statistics inserted in it depend on the premises; and the wide range of plausible alternatives can lead to widely divergent social judgments about the combined effect of taxes and governmental expenditures. 